\title{
RELEASE OF LH BY SYNTHETIC LH-RH IN THE MONKEY, MACACA FASCICULARIS
}

\author{
J. MORI* AND E. S. E. HAFEZ \\ Departments of Gynecology-Obstetrics and Physiology, \\ Wayne State University School of Medicine, \\ Detroit, Michigan, U.S.A.
}

(Received 27th November 1972)

\begin{abstract}
Summary. The effect in vivo of synthetic LH-RH was studied in intact monkeys. The intravenous administration of $400 \mathrm{ng}$ synthetic $\mathrm{LH}-\mathrm{RH}$ / head caused an increase in serum LH. A double peak in serum LH levels was observed. The first peak of serum LH levels was reached within 15 to $45 \mathrm{~min}$ after injection and the second peak within $1 \frac{1}{2}$ to $2 \mathrm{hr}$.
\end{abstract}

Since the discovery of $\mathrm{LH}$-releasing hormone (LH-RH) in the hypothalamic extracts of the rat (McCann, Taleisnik \& Friedman, 1960), its biological effects have been studied in several species (Schally and his co-authors, 1968). The chemical structure of porcine LH-RH was elucidated as (pyro)Glu-His-TrpSer-Tyr-Gly-Leu-Arg-Pro-Gly- $\mathrm{NH}_{2}$ (Matsuo, Baba, Nair, Arimura \& Schally, 1971; Baba, Matsuo \& Schally, 1971). This decapeptide has been synthesized (Matsuo, Arimura, Nair \& Schally, 1971) and its releasing activity tested in the rat (Arimura, Matsuo, Baba, Debeljuk, Sandow \& Schally, 1972), sheep (Reeves and his co-authors, 1972; Arimura, Debeljuk, Matsuo \& Schally, 1972) and man (Schally and his co-authors, 1971; Guillemin, 1972).

The aim of this study was to examine the effect in vivo of synthetic LH-RH on serum LH levels in crab-eating macaques, Macaca fascicularis.

Synthetic LH-RH $(10455 \times 151-2)$ used in this experiment has significant LH-releasing activity at $1.0 \mathrm{ng}$ in the Ramirez-McCann rat bioassay (J. R. Reel, personal communication).

Two male and four female adult crab-eating macaques were used in this study, one of the males and two of the females being used in the experimental, and the rest in the control, group. The monkeys were individually housed in laboratory cages in a ventilated air-filtered room at a constant temperature $\left(23^{\circ} \mathrm{C}\right)$, humidity $(40 \%)$ and daily photoperiod of $12 \mathrm{hr}$ light. Commercial food pellets and water were freely available and supplies were replenished daily.

Three monkeys, one male (No. 3) and two females (Nos 54 and 71), were given intravenous injections of $400 \mathrm{ng} \mathrm{LH}-\mathrm{RH}$. Blood samples were collected once $5 \mathrm{~min}$ before and seven to thirteen times after the injection (Text-fig. 1). The blood samples were taken from the saphenous veins, and the blood serum was kept at $-20^{\circ} \mathrm{C}$ until assay. Serum $\mathrm{LH}$ concentrations were determined by

* Present address: National Institute of Animal Industry, Chiba, Japan. 
the double antibody radioimmunoassay method (Niswender and his coauthors, 1971). The purified LH preparation for iodination was LER-1056-C2 and the antiserum to ovine LH was GDN-15. All of the results are expressed in terms of ng LER-M-907D.
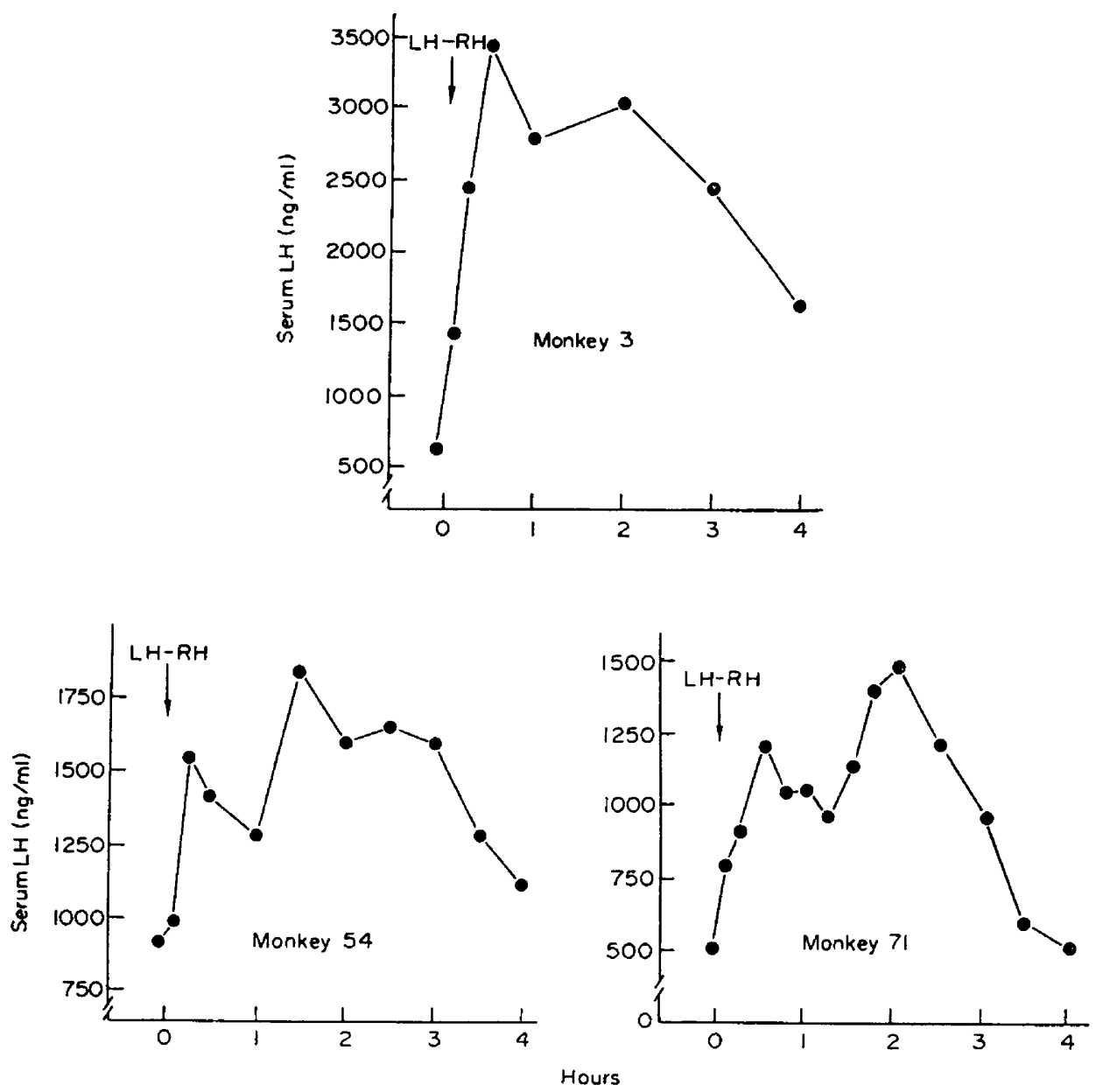

TExT-FIo. 1. Effect of intravenous injection of LH-RH on serum LH in three monkeys (one male: No. 3; two females: Nos 54 and 71).

Administration of LH-RH induced a considerable rise in serum $\mathrm{LH}$ in all three monkeys. The peak of serum LH levels was reached within 15 to $45 \mathrm{~min}$ after injection. The peak concentrations were approximately 5.6 (Monkey 3 ), 1.7 (Monkey 54) and 2.4 (Monkey 71) times higher than the respective pretreatment values. The peak levels of serum LH were followed by a gradual decline within 30 to $60 \mathrm{~min}$, after which time the LH levels again rose. A second peak was reached $1 \frac{1}{2}$ to $2 \mathrm{hr}$ after injection. This second peak was also followed by a gradual decline in LH levels. Serum LH concentrations of two monkeys out of three at $4 \mathrm{hr}$ after the injection were still higher than $\mathrm{LH}$ 
concentrations before injection. In contrast to the monkeys in the experimental group, the three control monkeys given the same amount of saline exhibited no marked changes in serum $\mathrm{LH}$ levels.

These results demonstrate that the synthetic LH-RH can induce an increase in the serum LH levels of male and female monkeys. However, the possibility that any endogenous alterations result from administered LH-RH which, in turn, plays some rôle in the increase, especially the second increase, in the levels still remains to be solved. Further studies on this point are in progress.

The authors are indebted to Dr J. R. Reel of Parke, Davis and Company for a gift of synthetic LH-RH, to Dr L. E. Reichert, Jr, for a gift of the purified hormones (LER-1056-C2 and LER-M-907D) and to Dr G. D. Niswender for a gift of antiserum (GDN-15) for radioimmunoassay. The investigation was supported by Ford Foundation Grant 710-0287.

\section{REFERENGES}

Arimura, A., Debeljuk, L., Matsuo, H. \& Schally, A. V. (1972) Release of luteinizing hormone by synthetic L.H-releasing hormone in the ewe and ram. Proc. Soc. exp. Biol. Med. 139, 851.

Artmura, A., Matsuo, H., Baba, Y., Debeljuk, L., Sandow, J. \& Schally, A. V. (1972) Stimulation of release of LH by synthetic LH-RH in vivo. I. A comparative study of natural and synthetic hormones. Endocrinology, 90, 163.

Baba, Y., Matsuo, H. \& Schally, A. V. (1971) Structure of the porcine LH- and FSH-releasing hormone. II. Confirmation of the proposed structure of conventional sequential analyses. Biochem. biophys. Res. Commun. 44, 459.

Guillemin, R. (1972) Physiology and chemistry of the hypothalamic releasing factors for gonadotrophins. A new approach to fertility control. Contraception, 5, 21.

McCann, S. M., Taleisnik, S. \& Friedman, H. M. (1960) LH-releasing activity in hypothalamic extracts. Proc. Soc. exp. Biol. Med. 104, 432.

Matsuo, H., Arimura, A., Nair, R. M. G. \& Schally, A. V. (1971) Synthesis of the porcine LHand FSH-releasing hormone by the solid phase method. Biochem. biophys. Res. Commun. 45, 822.

Matsuo, H., Baba, Y., Nair, R. M. G., Arimura, A. \& Schally, A. V. (1971) Structure of the porcine LH- and FSH-releasing hormone. I. The proposed amino acid sequence. Biochem. biophys. Res. Commun. 43, 1334.

Niswender, G. D., Monroe, S. E., Peckham, W. D., Midgley, A. R., Jr, Knobil, E. \& Reichert, L. E., JR (1971) Radioimmunoassay for rhesus monkey luteinizing hormone (LH) with antiovine LH serum and ovine LH-131 I. Endocrinology, 88, 1327.

Reeves, J. J., Arimura, A., Schally, A. V., Kragt, G. L., Beck, T. W. \& Gasey, J. M. (1972) Effects of synthetic luteinizing hormone-releasing hormone/follicle stimulating hormonereleasing hormone (LH-RH/FSH-RH) on serum LH, serum FSH and ovulation in anestrous ewes. F. Anim. Sci. 35, 84.

Schally, A. V., Arimura, A., Bowers, G. Y., Kastin, A. J., Sawano, S. \& Redding, T. W. (1968) Hypothalamic neurohormones regulating anterior pituitary function. Recent Prog. Horm. Res. 24, 497.

Schally, A. V., Arimura, A., Kastin, A. J., Matsuo, H., Baba, Y., Redding, T. W., Nair, R. M. G., DebeljuK, L. \& Whrte, W. F. (1971) Gonadotropin-releasing hormone: one polypeptide regulates secretion of luteinizing and follicle-stimulating hormones. Science, N.Y. 173, 1036. 